\title{
Sensitive species in a bad habitat - species richness of ichthyofauna in the strongly anthropogenically transformed Uszwica River (southern Poland)
}

\author{
Mariusz Klich ${ }^{a,}{ }^{*}$, Sabina Klich ${ }^{b}$ \\ ${ }^{a}$ University of Applied Sciences in Tarnow, ul. Mickiewicza 8, 33-100 Tarnów, Poland \\ ${ }^{b}$ Jagiellonian University in Kraków, Faculty of Biology, Institute of Botany, ul. Gronostajowa 3, 30-387 Kraków, Poland
}

\section{Article history}

Received: 23 July 2020

Received in revised form:

15 September 2020

Accepted: 14 October 2020

Available: 22 October 2020

\begin{abstract}
The Uszwica River is a $67 \mathrm{~km}$ long right-bank submountain tributary of the Vistula. From the beginning of the $20^{\text {th }}$ century the Uszwica was subjected to strong anthropopressure. The water course was disrupted at $\mathrm{km} \mathrm{37+300} \mathrm{with} \mathrm{a} \mathrm{5.3-meter-high} \mathrm{dam} \mathrm{in} \mathrm{the} \mathrm{town} \mathrm{of}$ Brzesko. Strong pollution of water in this town and numerous hydrotechnical alterations along almost the entire course of the river have negative influence on the river habitats. Despite this, the Uszwica is characterized by relatively rich ichthyofauna composed of 26 species, including 6 species which are legally protected in Poland and 7 species regarded threatened according to the Polish Red List of fish and lampreys [1]. The composition of ichthyofauna was determined on the basis of electrofishing along the entire river in 2004 and 2015, and on selected reaches in 2014 and 2018. The results show that even heavily anthropogenically transformed rivers may provide habitats for threatened fish species and should not be excluded from nature protection plans and projects.
\end{abstract}

Keywords: Uszwica River, ichthyofauna, anthropopressure, protected species, a red list of fish and lampreys

\section{Introduction}

Freshwater ecosystems, especially rivers, belong to the most endangered components of the environment. The dynamic progress of civilization, which took place in the nineteenth and twentieth centuries, along with the unprecedented development of technical thought in the history of mankind, brought about a radical improvement in the standard of living of the societies of urbanized regions. During the civilizational progress, however, the problem of deep anthropogenic transformations of the natural environment arose. This is particularly evident in the case of flowing waters. Pollution, regulation and fragmentation of rivers have led to decline or extinction of populations of fish species. Many of them were now probably on the brink. In numerous rivers and dam reservoirs periodic or permanent destruction of the Fish communities were recorded [2]. These most endangered species which disappear as the first should be considered as most valuable in terms of nature protection.

There are many elements to assess the state of water purity. Physicochemical analyses allow to examine the current state of water quality, which is variable over time [3].

\footnotetext{
*Corresponding author: ekorybyl@wp.pl
}

They provide knowledge about the sources and type of pollution, but not about the long-term state of the river. Although they are very precise, their results show only a temporary state of water quality. In order to assess the state of the entire watercourse well and determine the changes occurring in longer period, biological methods should be used. According to the EU Water Framework Directive [4], the main groups of aquatic organisms are used to assess the biological status of rivers, such as: ichthyofauna, benthic macroinvertebrates, macrophytes and phytobenthos. Moreover, hydromorphological characteristics of the river are assessed.

To develop a strategy for the protection of degraded river ecosystems, the knowledge about them is necessary. An example of considerably degraded small river is the Uszwica in the basin of the Upper Vistula in southern Poland. The data on the ichthyofauna of this river are scarce. In 1993 an investigation of the ichthyofauna in some reaches of the river was carried out, but the obtained results have not been published and now they are out of date. More recent data were presented by Bartnik et al. [5] in a general description of the ichthyofauna of the Upper Vistula and its major tributaries. However, no information on sampling sites and dates was provided. 
This paper presents results of ichthyofaunistic study collected in the Uszwica in the period 2004-2018. The aim of the study was to determine the species composition of fish community of a small river exposed to human impact typical of submontane areas of Polish part of Carpathians, with particular emphasis on possibility to survive of rare, protected and endangered species there.

\section{Research Area, Materials and Methods}

\section{Research Area}

The Uszwica is a right-bank tributary of the Vistula with a length of about $67 \mathrm{~km}$ and a catchment area of about 323 $\mathrm{km} 2$. The springs of the river begin on the northern slopes of the Beskid Wyspowy mountains, at altitude of about 500 $\mathrm{m}$, near the Rajbrot village $\left(49^{\circ} 48^{\prime} 14^{\prime \prime} \mathrm{N}, 20^{\circ} 30^{\prime} 19^{\prime \prime} \mathrm{E}\right)$. It inflows into the Vistula in the Wola Przemykowska village $\left(50^{\circ} 11^{\prime} 22^{\prime \prime} \mathrm{N}, 20^{\circ} 39^{\prime} 35^{\prime \prime} \mathrm{E}\right)$ at $174 \mathrm{~m}$ above sea level. For the purposes of this study, the Uszwica was divided into four ecologically different zones.

The first zone was the semi-natural upper section from the sources to the beginning of the impact of the Brzesko and Okocim agglomerations (67 to $39 \mathrm{~km}$ ). It is characterized by small anthropogenic transformations. In its beginning the Uszwica flows through densely settled villages. Despite this, the stream channel is altered to a small extent and is not embanked. The width of the channel near spring is up to $0.7 \mathrm{~m}$ and the depth to $20 \mathrm{~cm}$. In the upper part of its course, it flows through the Landscape Park of Wiśnicz and Lipnica (Pol. Wiśnicko-Lipnicki Park Krajobrazowy). A variety of landforms, local geology, hydrology and climatic zonation effect there in occurrence of different stream habitats and diverse living conditions for fish in the Uszwica and its tributaries. Despite some anthropogenic alterations within villages, there are still many natural parts with a mosaic of foraging habitats and hiding places, conducive to the existence of fish. Above Brzesko the river reaches a width of 5-7 $\mathrm{m}$ with an average depth of 30-60 cm. However, there are a few deeper parts, up to 2 meters. Within this section, the bottom substrate is dominated by stones and gravel (Fig. 1).

The second, central, zone is strongly degraded. It begins at Okocim village and ends in Bielcza village, extending from $\mathrm{km} 39$ to 18.2 of river course. It is characterized by large transformations of the environment, mainly expressed by pollution and hydrotechnical alterations. Some channel reaches are completely canalized what deteriorates living conditions for stream biota. There is a lack of hiding places for fish, no natural habitat diversity and reduced self-purification capacity of the river. Within this section one of the most important of the negative impacts on the Uszwica is located at $\mathrm{km} 37+300$ (495 $\left.57^{\prime} 42^{\prime \prime} \mathrm{N}, 20^{\circ} 35^{\prime} 37^{\prime \prime} \mathrm{E}\right)$.

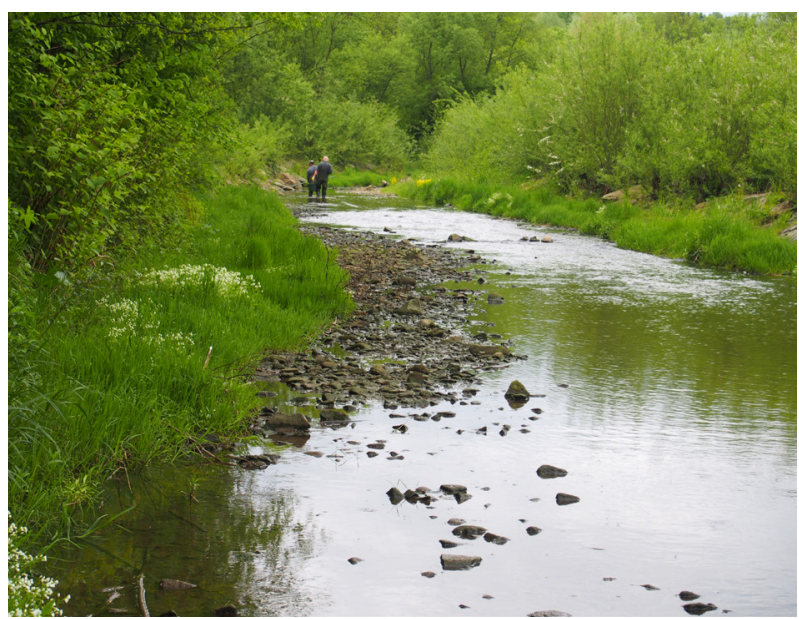

Figure 1. Uszwica River in Lipnica Murowana village in the upper seminatural zone of river course (zone 1) [photo by S. Klich, 13.05.2015]

Solid concrete weir $5.3 \mathrm{~m}$ high built in 1913 is a serious migration barrier for all aquatic organisms (Fig. 2). It causes permanent division of the river into two parts, the upper part of the length of $29.7 \mathrm{~km}$ ( $44.3 \%$ of the length of the river) and the lower part, $37.3 \mathrm{~km}$ long, downstream to the mouth to the Vistula.

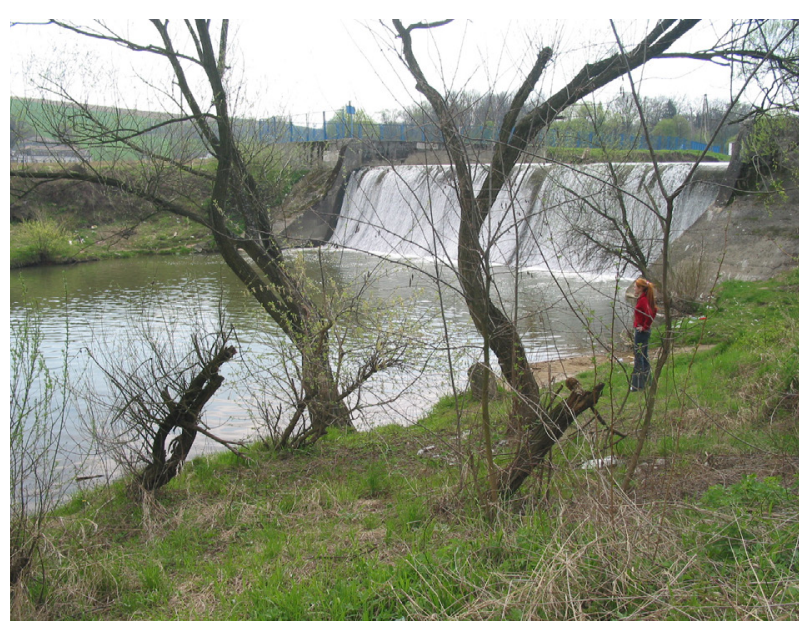

Figure 2. Uszwica River in Brzesko. The $5.3 \mathrm{~m}$ high weir built in 1913 was not equipped with any device for animal migration until 2020 [photo by M. Klich, 20.04.2004]

This part of the Uszwica is considerably polluted and silted (Fig. 3) because the water and wastewater management was carried out wrongly in the municipal area of Brzesko for years. It is probably still a problem, despite the new sewage treatment plant was put into use in 2001 . 
In the third zone dilution and self-purification processes of pollution from upstream reach are completed. The section stretches between the Bielcza and Kwików villages (from km 18.2 to 4.8). It is characterized by large environmental transformations including partial channel modification and pollution, mainly coming from agriculture. Sand and gravel dominate in the bottom substrate. Below the Borzęcin village ( $\mathrm{km} \mathrm{14.2)}$ Uszwica is embanked, the bed is often straight and the floodplain area is drained. Fields and meadows are located in riparian zone. The incision of channel amounts to about 3.5-6 m, the width of the river 5-10 m, and a depth of 10 to $180 \mathrm{~cm}$ (Fig. 4). There are fewer villages along the river than in the upper and middle sections, and with the exception of Borzęcin, they are located at some distance from the river.

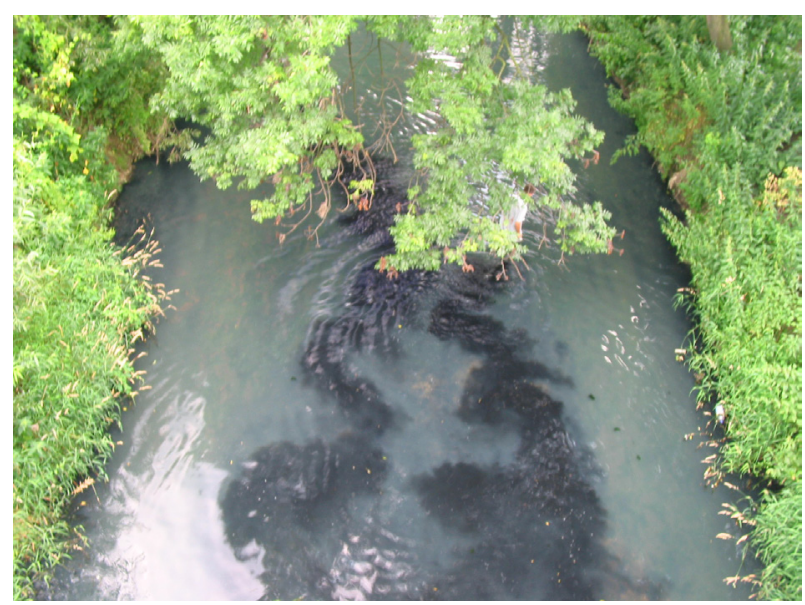

Figure 3. Uszwica River in polluted section below the town of Brzesko. The photography was taken after wading during electrofishing. Raised black mud deposited on the bottom is visible, which layer amounts to about $0.5 \mathrm{~m}$ [photo by M. Klich, 23.07.2004]

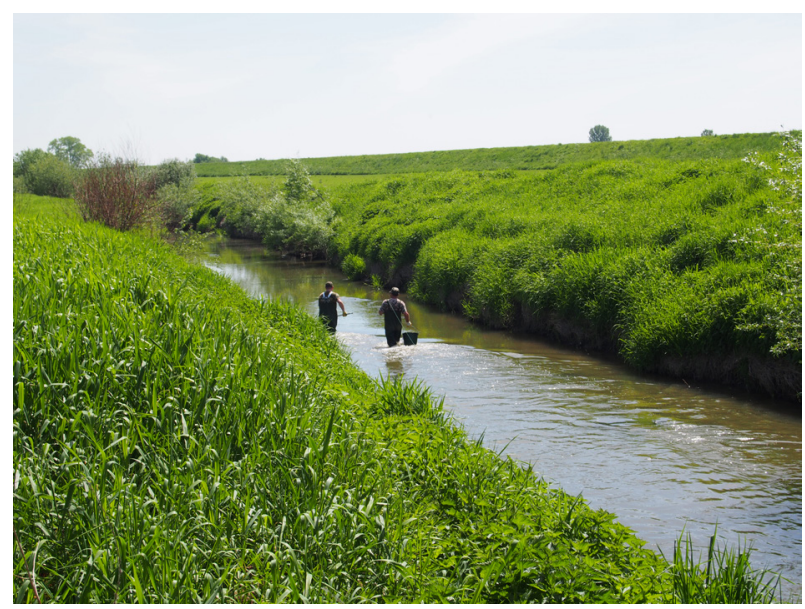

Figure 4. Uszwica River below the Borzęcin village (zone 3), about $10 \mathrm{~km}$ from the mouth to the Vistula [photo by S. Klich, 12.05.2015]
The fourth zone of the Uszwica River is influenced by the recipient - the Vistula. The water from the Vistula mix with the water of Uszwica. Moreover, fish can migrate between the rivers. The fourth zone of the Uszwica River stretches from the Kwików to Wola Przemykowska village near to the mouth to the Vistula (from $\mathrm{km} 4.8$ to 0.0 ).

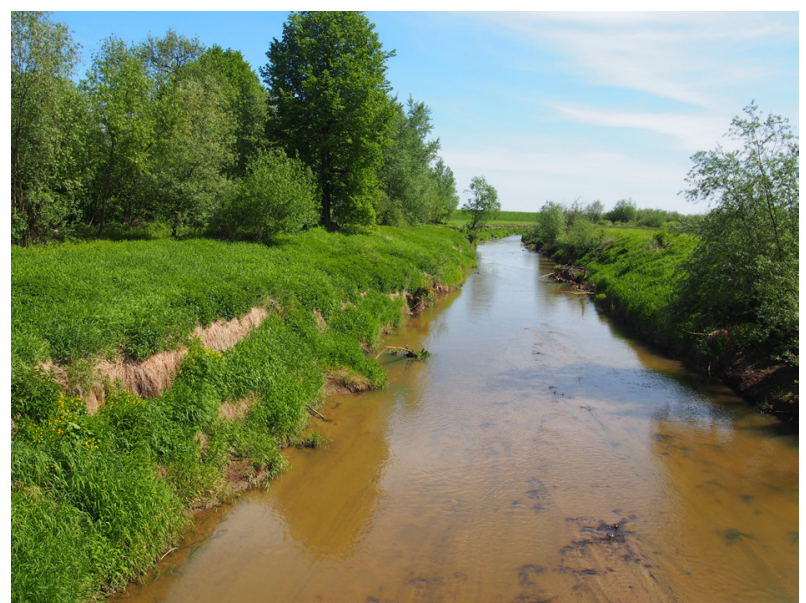

Figure 5. Uszwica River in Wola Przemykowska village (zone 4) about $1 \mathrm{~km}$ from the mouth into the Vistula [photo by M. Klich, 12.05.2015]

The width of the river amounts to $13-16 \mathrm{~m}$, depth ranges from 40 to $180 \mathrm{~cm}$. The river mouth section remains under the influence of the Vistula, and therefore it is very shallow at the last kilometer of river course, usually below $50 \mathrm{~cm}$. The current is slow, the bottom is sandy and muddy in some parts. The distance between flood embankments is small, from 50 to 100 meters and it is overgrown with trees: mainly willow, birch, and alder (Fig. 5).

\section{Fishing Methods and Sampling Sites}

Fish were caught by electrofishing in twelve reaches distributed along the entire river in the autumn of 2004 and autumn of 2015. They were designated in such a way as to be representative of all river habitats (Fig. 6). In 2004, part of the catches in deeper channel reaches were carried out from the boat. Later, due to the low water level, only wading was possible. Fishes were caught within reaches of equal length of 300 meters. In a few cases, when sampled reaches were longer the results were converted for distance of $300 \mathrm{~m}$. Additional catches were made in six selected reaches in 2014 and 2018.

The fish caught during electrofishing were marked and measured: the total length (longitudo totalis) and the length of the body (longitudo corporis), with an accuracy of $0.1 \mathrm{~cm}$ and weighed with an accuracy of $1 \mathrm{~g}$. After the measurements, the 
fish was immediately released into the water. All fish after the measurements were in good condition and without any negative symptoms floated away. The catches in 2004 and 2015 were carried out jointly with the fishing user of the river, the Polish Angling Association in Tarnów, which received some of the data for its own needs $[6,7]$.

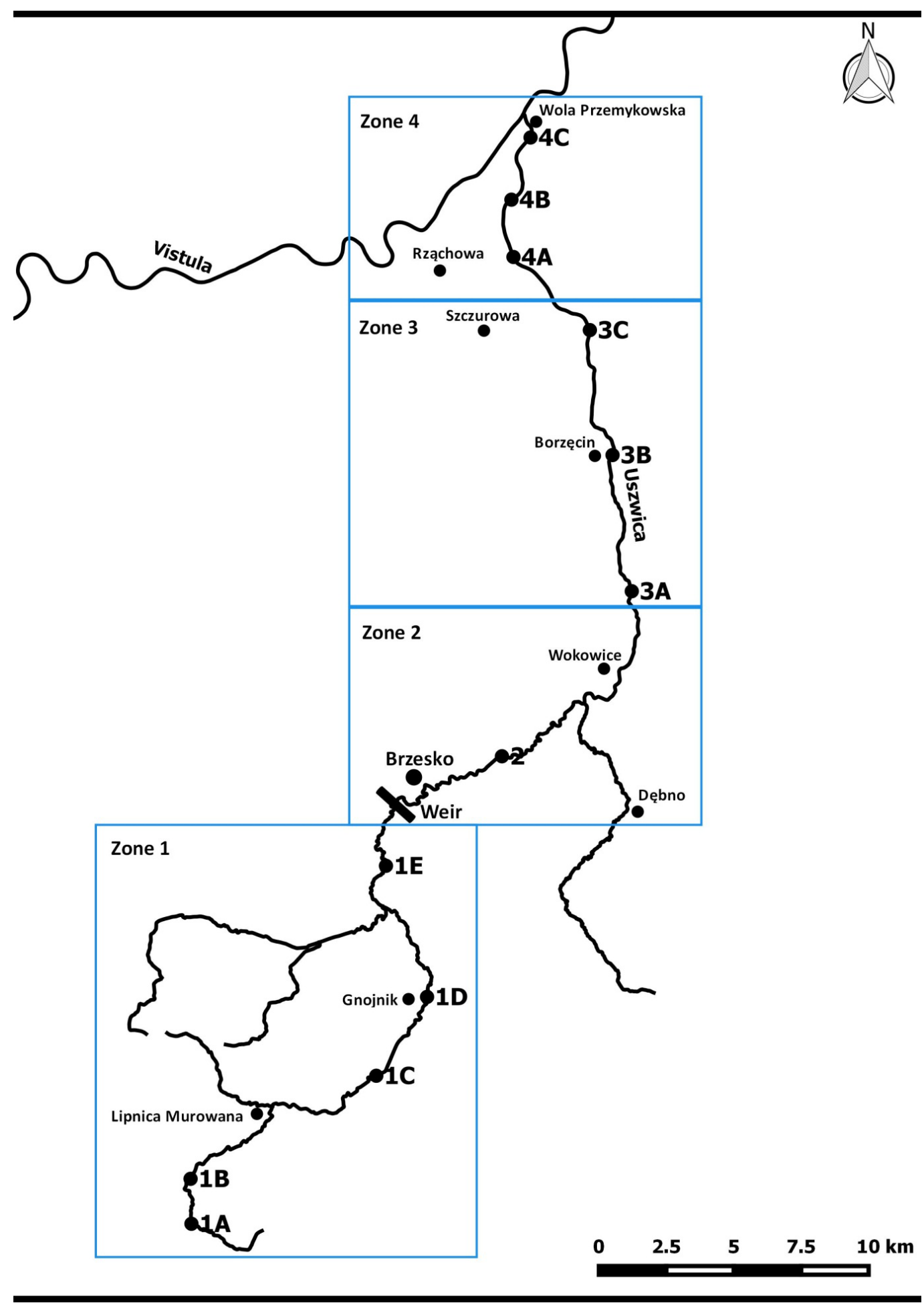

Figure 6. Location of sampling sites in the Uszwica River investigated in 2004, 2014, 2015 and 2018 (fishing zones are marked in blue squares) 


\section{Results}

From 3 to 14 fish species were collected at 12 investigated sites. In the most polluted sampling site below Brzesko (site no. 6, distance $1 \mathrm{~km}$ ), no fish was caught. Results obtained in 2004 and 2015 were similar (Fig. 7).

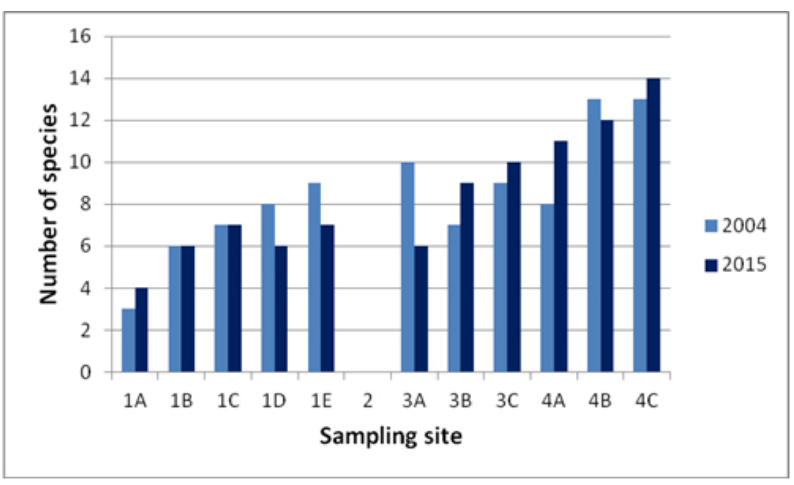

Figure 7. Species richness of ichthyofauna in the Uszwica River (locations of sampling sites are presented in Fig. 6)

Highest density was recorded in Rajbrot and Lipnica Murowana (Fig. 8), but it should be noted that small-sized species, mainly European minnow, Phoxinus phoxinus occurred there. The density of fish expressed in the numbers of individuals decreases to zero in the direction of the heavily contaminated section and then increases again along the river.
The species composition of fish caught in the Uszwica was analyzed within the four zones of this river: 1) the upper, semi-natural zone, 2) heavily polluted middle zone, 3 ) the lower zone with self-cleaning processes, 4) mouth zone exposed to the influence of the recipient. The number of fishing sites in individual zones varied. That is why the number of fish caught in the zones was calculated by adding the results from the sites and dividing them in such a way as to obtain the number of fish in the 300-meter river section. Five classes of fish sizes were distinguished (Tab. 1).

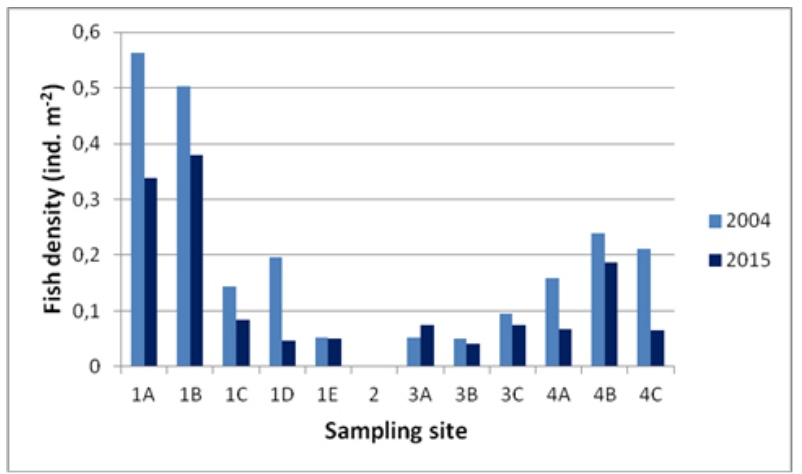

Figure 8. Density of fish caught in the Uszwica River (locations of sampling sites are presented in Fig. 6)

Table 1. The occurrence of fish species in catches collected along the Uszwica in 2004 and 2015, and at selected sites in 2014 and 2018. The results were presented for $300 \mathrm{~m}$ long sections. The main environmental characteristics of particular zones are following: 1-headwater semi-natural, 2-strongly polluted, 3-lowland channelized, 4 - near to mouth to the Vistula (for detailed explanation see „Research Area”). Densal compartments of fish: A: > 100, B: 51-100, C: 11-50, D: 6-10, E: 1-5 individuals

\begin{tabular}{|c|c|c|c|c|c|c|c|c|c|c|c|c|}
\hline \multirow{2}{*}{ No. } & \multirow{2}{*}{ Species } & \multicolumn{3}{|c|}{ Zone 1} & \multicolumn{3}{|c|}{ Zone 2} & \multicolumn{2}{|c|}{ Zone 3} & \multicolumn{3}{|c|}{ Zone 4} \\
\hline & & 2004 & 2014 & 2015 & 2004 & 2015 & 2018 & 2004 & 2015 & 2004 & 2015 & 2018 \\
\hline 1 & Abramis bjoerkna & & & & & & & $\mathrm{E}$ & $\mathrm{E}$ & $\mathrm{E}$ & $\mathrm{C}$ & \\
\hline 2 & Alburnoides bipunctatus & $\mathrm{C}$ & $\mathrm{C}$ & E & & & $\mathrm{E}$ & & & & & \\
\hline 3 & Alburnus alburnus & & & & & & & $\mathrm{C}$ & & A & B & $\mathrm{E}$ \\
\hline 4 & Barbus barbus & & & & & & & & $\mathrm{E}$ & & & \\
\hline 5 & Barbus carpathicus & $\mathrm{C}$ & B & $\mathrm{C}$ & & $\mathrm{D}$ & $\mathrm{E}$ & & & & & \\
\hline 6 & Carassius auratus & E & & & & & & $\mathrm{E}$ & E & E & & \\
\hline 7 & Chondrostoma nasus & & & E & & & & & & $\mathrm{E}$ & & \\
\hline 8 & Gobio gobio & $\mathrm{C}$ & $\mathrm{C}$ & $\mathrm{C}$ & & $\mathrm{C}$ & B & $\mathrm{C}$ & $\mathrm{C}$ & $\mathrm{C}$ & $\mathrm{C}$ & $\mathrm{C}$ \\
\hline 9 & Leucaspius delineatus & $\mathrm{E}$ & & & & & & & & & & \\
\hline 10 & Leuciscus idus & & & $\mathrm{E}$ & & $\mathrm{E}$ & & & $\mathrm{E}$ & E & $\mathrm{D}$ & $\mathrm{E}$ \\
\hline 11 & Leuciscus leuciscus & $\mathrm{E}$ & & $\mathrm{E}$ & & $\mathrm{D}$ & $\mathrm{C}$ & $\mathrm{C}$ & E & $\mathrm{C}$ & $\mathrm{C}$ & \\
\hline 12 & Phoxinus phoxinus & A & B & & & & & $\mathrm{E}$ & & & & \\
\hline 13 & Pseudorasbora parva & & & & & & & & & & & $\mathrm{E}$ \\
\hline 14 & Rhodeus amarus & & & & & & & & & & & $\mathrm{E}$ \\
\hline 15 & Rutilus rutilus & & & & & & & $\mathrm{E}$ & E & $\mathrm{D}$ & $\mathrm{C}$ & $\mathrm{E}$ \\
\hline 16 & Squalius cephalus & $\mathrm{C}$ & $\mathrm{C}$ & $\mathrm{C}$ & & $\mathrm{C}$ & $\mathrm{B}$ & $\mathrm{C}$ & $\mathrm{C}$ & $\mathrm{C}$ & $\mathrm{C}$ & $\mathrm{C}$ \\
\hline
\end{tabular}




\begin{tabular}{|c|c|c|c|c|c|c|c|c|c|c|c|c|}
\hline \multirow{2}{*}{ No. } & \multirow{2}{*}{ Species } & \multicolumn{3}{|c|}{ Zone 1} & \multicolumn{3}{|c|}{ Zone 2} & \multicolumn{2}{|c|}{ Zone 3} & \multicolumn{3}{|c|}{ Zone 4} \\
\hline & & 2004 & 2014 & 2015 & 2004 & 2015 & 2018 & 2004 & 2015 & 2004 & 2015 & 2018 \\
\hline \multirow[t]{2}{*}{17} & Vimba vimba & & & & & & & & & $\mathrm{E}$ & & \\
\hline & COBITIDAE & & & & & & & & & & & \\
\hline 18 & Cobitis taenia & & & & & & & $\mathrm{E}$ & E & $\mathrm{E}$ & $\mathrm{E}$ & $\mathrm{E}$ \\
\hline \multirow[t]{2}{*}{19} & Misgurnus fossilis & & & & & & & & $\mathrm{E}$ & $\mathrm{E}$ & $\mathrm{E}$ & \\
\hline & BALITORIDAE & & & & & & & & & & & \\
\hline 20 & $\begin{array}{l}\text { Barbatula barbatula } \\
\text { ESOCIDAE }\end{array}$ & B & B & B & & $\mathrm{D}$ & A & $\mathrm{D}$ & $\mathrm{D}$ & $\mathrm{C}$ & $\mathrm{C}$ & $\mathrm{C}$ \\
\hline \multirow[t]{2}{*}{21} & Esox lucius & & & & & & & $\mathrm{E}$ & E & $\mathrm{E}$ & $\mathrm{E}$ & \\
\hline & SALMONIDAE & & & & & & & & & & & \\
\hline \multirow[t]{2}{*}{22} & Salmo trutta m. fario & $\mathrm{E}$ & $\mathrm{C}$ & $\mathrm{C}$ & & & & & & & & \\
\hline & GADIDAE & & & & & & & & & & & \\
\hline \multirow[t]{2}{*}{23} & Lota lota & & & & & & & & $\mathrm{E}$ & & $\mathrm{E}$ & \\
\hline & PERCIDAE & & & & & & & & & & & \\
\hline 24 & Gymnocephalus cernua & & & & & & & & & $\mathrm{E}$ & $\mathrm{E}$ & \\
\hline 25 & Perca fluviatilis & & & & & & & $\mathrm{E}$ & $\mathrm{C}$ & $\mathrm{D}$ & $\mathrm{C}$ & $\mathrm{E}$ \\
\hline 26 & Stizostedion lucioperca & & & & & & & & & & & $\mathrm{E}$ \\
\hline
\end{tabular}

\section{Discussion and Conclusions}

The natural value of the Uszwica as a fish habitat is determined mainly by the number of species considered endangered, rare or sensitive to anthropopressure. The IUCN Red List Categories and Criteria were introduced for evaluation risk of species decline and extinction $[8,9]$. Such species are presented in the Red Lists and Red Data Books have been developed systematically based on the current available knowledge about the state of the fish fauna in Polish waters [1, 10-12]. In the Uszwica seven threatened species were recorded: one Critically endangered, two Endangered, and four Vulnerable (Tab. 2). This local ichthyofauna contains six legally protected species [13], four listed in Annex II, and two in Annex V of the Habitats Directive $[17,14]$. In total, ten threatened and/or protected species occur in the Uszwica, and this number amounts to $38 \%$, i.e. roughly $2 / 5$ of all species recorded there (Tab. 2). The species listed in Annex II, Carpathian barbel Barbus carpathicus, European bitterling Rhodeus amarus, spined loach Cobitis taenia, and weatherfish Misgurnus fossilis, require designation of special areas of conservation. In case of common barbel Barbus barbus the Habitats Directive allows explotation, and the local population is subjected to legal size.

In Poland 5 species of fish are subject to strict species protection, none of them occurs in Uszwica, but it should be emphasized that Uszwica was never a natural habitat for these species

Table 2. Threat categories and legal protection in Poland and the EU of fish species recorded in the Uszwica in 2004, 2014, 2015, and 2018

\begin{tabular}{|c|c|c|c|c|c|c|}
\hline No. & Species & $\begin{array}{c}\text { Threat cat- } \\
\text { egory in the } \\
\text { Vistula basin } \\
{[1]}\end{array}$ & $\begin{array}{l}\text { Legal protec- } \\
\text { tion in Poland } \\
\text { (partial pro- } \\
\text { tection) [13] }\end{array}$ & $\begin{array}{l}\text { Annex II of } \\
\text { Habitats Di- } \\
\text { rective [17] }\end{array}$ & $\begin{array}{l}\text { Annex } \mathrm{V} \text { of } \\
\text { Habitats Di- } \\
\text { rective [17] }\end{array}$ & Alien species \\
\hline & \multicolumn{6}{|l|}{ CYPRINIDAE } \\
\hline 1 & Abramis bjoerkna & $\mathrm{LC}$ & & & & \\
\hline 2 & Alburnoides bipunctatus & $\mathrm{EN}$ & + & & & \\
\hline 3 & Alburnus alburnus & $\mathrm{LC}$ & & & & \\
\hline 4 & Barbus barbus & VU & & & + & \\
\hline 5 & Barbus carpathicus & NT & + & + & + & \\
\hline 6 & Carassius auratus & & & & & + \\
\hline 7 & Chondrostoma nasus & EN & & & & \\
\hline 8 & Gobio gobio & $\mathrm{LC}$ & & & & \\
\hline
\end{tabular}




\begin{tabular}{|c|c|c|c|c|c|c|}
\hline No. & Species & $\begin{array}{c}\text { Threat cat- } \\
\text { egory in the } \\
\text { Vistula basin } \\
\text { [1] }\end{array}$ & $\begin{array}{l}\text { Legal protec- } \\
\text { tion in Poland } \\
\text { (partial pro- } \\
\text { tection) [13] }\end{array}$ & $\begin{array}{l}\text { Annex II of } \\
\text { Habitats Di- } \\
\text { rective [17] }\end{array}$ & $\begin{array}{l}\text { Annex V of } \\
\text { Habitats Di- } \\
\text { rective [17] }\end{array}$ & Alien species \\
\hline 9 & Leucaspius delineatus & LC & & & & \\
\hline 10 & Leuciscus idus & LC & & & & \\
\hline 11 & Leuciscus leuciscus & $\mathrm{LC}$ & & & & \\
\hline 12 & Phoxinus phoxinus & LC & & & & \\
\hline 13 & Pseudorasbora parva & & & & & + \\
\hline 14 & Rhodeus amarus & VU & + & + & & \\
\hline 15 & Rutilus rutilus & $\mathrm{LC}$ & & & & \\
\hline 16 & Squalius cephalus & $\mathrm{LC}$ & & & & \\
\hline \multirow[t]{2}{*}{17} & Vimba vimba & $\mathrm{CR}$ & & & & \\
\hline & COBITIDAE & & & & & \\
\hline 18 & Cobitis taenia & $\mathrm{LC}$ & + & + & & \\
\hline \multirow[t]{2}{*}{19} & Misgurnus fossilis & NT & + & + & & \\
\hline & BALITORIDAE & & & & & \\
\hline \multirow[t]{2}{*}{20} & Barbatula barbatula & LC & + & & & \\
\hline & ESOCIDAE & & & & & \\
\hline \multirow[t]{2}{*}{21} & Esox lucius & $\mathrm{LC}$ & & & & \\
\hline & SALMONIDAE & & & & & \\
\hline \multirow[t]{2}{*}{22} & Salmo trutta m. fario & $\mathrm{CD}$ & & & & \\
\hline & GADIDAE & & & & & \\
\hline \multirow[t]{2}{*}{23} & Lota lota & $\mathrm{VU}$ & & & & \\
\hline & PERCIDAE & & & & & \\
\hline 24 & Gymnocephalus cernua & $\mathrm{LC}$ & & & & \\
\hline 25 & Perca fluviatilis & $\mathrm{LC}$ & & & & \\
\hline 26 & Stizostedion lucioperca & $\mathrm{LC}$ & & & & \\
\hline
\end{tabular}

$[13,15,16]$. In Uszwica there are 6 species of fish under partial protection in Poland, and probably in Uszwica there were never any other species currently under protection in Poland (Tab. 2) [13, 14, 5]. There are 4 fish species of EU interest in Uszwica, which require the establishment of the Nature 2000 network (Tab. 2) [17].

An important indicator of the condition of the rivers' environment is species diversity, the simplest indicator of which is species richness. In Poland, 56 species of freshwater fish are formally considered native [14]. Fish fauna in the Uszwica is composed of 24 native species, i.e. of nearly half of Polish ichthyofauna. Only two alien species were recorded there, both of them are considered invasive (Tab. 2). Some of the native species of fish are rare in Poland and have a small range. These species include fish associated with high-mountain areas, living in coastal estuaries of rivers, or fish found only in natural lakes. Therefore, the natural occurrence of 24 fish species in Uszwica is a satisfactory result. The local species richness can be compared with data from other Polish rivers physiographically similar to the Uszwica, among them with those which may offer potentially better habitats for fish, due to their larger size or lower human impact. Twelve studies carried out with similar methods were selected for this comparison (Tab. 3).

In order to assess the species richness of the ichthyofauna in Uszwica river, the obtained results should be compared with other rivers in Poland, tested using similar methods. It should be emphasized that there are not many such studies. Few studies of this type have been published in the last 20 years. Even if rivers were surveyed, they were often surveyed only once or twice, or not along its entire length [18-20].

Fish are one of the basic bioindicators of the quality of the aquatic environment. They signal very quickly any disturbances in the biocenosis of rivers. The qualitative and quantitative structure of the fish community is treated as the best biological indicator of the condition of the aquatic ecosystem. This is due to the fact that the image of the ichthyofauna shows not only temporary, incidental events, but also includes changes that are difficult to notice in a short time and are taking place over many years [2].

Rivers in Poland are subject to many pressures, such as chemical and physical pollution, regulations, river partitioning, poaching or poorly conducted or lacking fishing management, 
Table 3. Species richness in selected Carpathian rivers and streams

\begin{tabular}{|c|c|c|c|c|c|c|c|}
\hline No. & The name of the river & $\begin{array}{l}\text { Number of } \\
\text { fish species }\end{array}$ & $\begin{array}{l}\text { Threatened } \\
\text { species [1] }\end{array}$ & $\begin{array}{c}\text { Protected } \\
\text { species [13] }\end{array}$ & $\begin{array}{c}\text { Annex II or } \\
\text { V of Habitats } \\
\text { Directive } \\
{[17]}\end{array}$ & $\begin{array}{l}\text { Distance } \\
\text { from the } \\
\text { lowest sam- } \\
\text { pling side } \\
\text { from source } \\
(\mathrm{km})\end{array}$ & $\begin{array}{l}\text { Drainage } \\
\text { area }\left(\mathrm{km}^{2}\right)\end{array}$ \\
\hline 1 & Wisłoka [21] & 23 & 8 & 3 & 2 & 114 & 4110 \\
\hline 2 & Biała Tarnowska [22] & 21 & 9 & 4 & 2 & 101 & 983 \\
\hline 3 & Dunajec [23] & 26 & 11 & 4 & 3 & 248 & 6804 \\
\hline 4 & Szwedka [22] & 8 & 3 & 3 & 1 & 22 & 73 \\
\hline 5 & Wątok [22] & 3 & 1 & 1 & 0 & 23 & 85 \\
\hline 6 & Czarny Dunajec [24] & 8 & 4 & 3 & 1 & 48 & 456 \\
\hline 7 & Biały Dunajec [25] & 8 & 4 & 3 & 1 & 31 & 224 \\
\hline 8 & Kamienica Nawojowska [26] & 14 & 5 & 3 & 1 & 33 & NDA \\
\hline 9 & Raba [27] & 11 & 6 & 4 & 2 & 95 & 1537 \\
\hline 10 & Soła $[28]$ & 27 & 12 & 6 & 3 & 89 & 1375 \\
\hline 11 & $\begin{array}{l}\text { Vistula [29] (Vistula from its sources to } \\
\text { the mouth of the San River) }\end{array}$ & 33 & 12 & 4 & 3 & 360 & 194,424 \\
\hline 12 & San [30] (lower section) & 22 & 7 & 2 & 2 & 443 & 16,861 \\
\hline 13 & Uszwica (this study) & 26 & 7 & 6 & 5 & 67 & 323 \\
\hline
\end{tabular}

river valley transformations including deforestation, and alien and invasive species [1, 19, 20, 31]. Most, if not all, these pressures are subject to the Uszwica river. On the other hand, the spatial structure of ichthyofauna in the Uszwica in relation to other rivers in Poland (Tab. 3) leads to the surprising conclusion that this river offer habitats for many fish species considered to be sensitive and environmentally demanding. Therefore, the presented results suggest that rivers subjected to strong anthropopressure should not always be considered a bad habitat for fish without prior research. This conclusion should also be known to decision-making bodies in the field of river management, which unfortunately often too easily qualify rivers as heavily transformed, which inclines making environmentally inaccurate decisions leading to further degradation of valuable river ecosystems.

\section{Author Contributions}

Conceptualization, Mariusz Klich and Sabina Klich; methodology, Mariusz Klich and Sabina Klich; software, Mariusz Klich and Sabina Klich; validation, Mariusz Klich and Sabina Klich; formal analysis, Mariusz Klich and Sabina Klich; investigation, Mariusz Klich and Sabina Klich; resources, Mariusz Klich and Sabina Klich; data curation, Mariusz Klich and Sabina Klich; writing — original draft preparation, Mariusz Klich; writing — review and editing, Mariusz Klich and Sabina Klich; visualization, Mariusz Klich; supervision, Sabina Klich; project administration, Mariusz Klich; funding acquisition, Mariusz Klich and Sabina Klich.

\section{References}

1. Witkowski A, Kotusz J, Przybylski M. Stopień zagrożenia słodkowodnej ichtiofauny Polski: Czerwona lista minogów i ryb - stan 2009. Chrońmy Przyrodę Ojczystą. 2009;65(1):33-52.

2. Wiśniewolski W. Czynniki sprzyjające i szkodliwe dla rozwoju i utrzymania populacji ryb w wodach płynących. Supplementa ad Acta Hydrobiologica. 2002;3:1-28.

3. Kołodziejczyk A, Koperski P, Kamiński M. Klucz do oznaczania słodkowodnej makrofauny bezkręgowej dla potrzeb bioindykacji stanu środowiska. Warszawa: PIOŚ; 1998.

4. Directive 2000/60/EC of the European Parliament and of the Council of 23 October 2000 establishing a framework for Community action in the field of water policy. Official Journal L 327, 22/12/2000, P. 0001-0073. Available at: https://eur-lex.europa.eu/eli/dir/2000/60/2014-11-20 [accessed: 2020-10-26].

5. Bartnik W, Epler P, Jelonek M, Klaczak A, Książek L, Mikołajczyk T, Nowak M, Popek W, Sławińska A, Sobieszczyk P, Szczerbik P, Wyrębek M. Fisheries management with relation to the restoration of connectivity of the Little and the Upper Vistula River basins. Kraków: Komisja 
Technicznej Infrastruktury Wsi PAN, Stowarzyszenie Infrastruktura i Ekologia Terenów Wiejskich; 2011.

6. Klich M. Sprawozdanie z badań ichtiofauny rzeki Uszwica w roku 2004. [Unpublished report prepared for Polish Angling Association-Regional Management Office in Tarnów]. Tarnów: Polski Związek Wędkarski; 2004.

7. Klich M, Jarek S. Inwentaryzacja faunistyczna Uszwicy sprawozdanie z badań ichtiofauny rzeki Uszwica obwód rybacki nr $1 \mathrm{w}$ roku 2015. [Unpublished report prepared for Polish Angling Association-Regional Management Office in Tarnów]. Tarnów: Polski Związek Wędkarski; 2015.

8. IUCN Red List Categories and Criteria: version 3.1. 2nd ed. Gland, Cambridge: IUCN; 2012.

9. Guidelines for using the IUCN Red List Categories and Criteria: version 14. IUCN Standards and Petitions Committee; 2019. Available at: http://www.iucnredlist.org/documents/RedListGuidelines.pdf.

10. Witkowski A, Błachuta J, Kotusz J, Heese T. Czerwone lista słodkowodnej ichtiofauny Polski. Chrońmy Przyrodę Ojczystą. 1999;55:5-19.

11. Głowaciński Z, editor. Czerwona lista zwierząt ginących i zagrożonych w Polsce. Kraków: Instytut Ochrony Przyrody PAN, Oficyna Wydawnicza “TexT”; 2002.

12. Głowaciński Z, editor. Polska czerwona księga zwierząt: kręgowce. Warszawa: Państwowe Wydawnictwo Rolnicze i Leśne; 2001.

13. Rozporządzenie Ministra Środowiska z dnia 16 grudnia 2016 r. w sprawie ochrony gatunkowej zwierząt [Regulation of the Minister of Environment of 16 December 2016 on legal protection of animal species]. Dziennik Ustaw [Journal of Laws of the Republic of Poland]; 2016, item 2183 .

14. Rozporządzenie Ministra Rolnictwa i Rozwoju Wsi z dnia 16 listopada 2012 r. w sprawie wykazu gatunków ryb uznanych za nierodzime i wykazu gatunków ryb uznanych za rodzime oraz warunków wprowadzania gatunków ryb uznanych za nierodzime, dla których nie jest wymagane zezwolenie na wprowadzenie. [Regulation of the Minister of Agriculture and Rural Development of 16 November 2012 on the list of fish species regarded non-native and the list of fish species regarded native, and the conditions of introduction of fish species regarded non-native, for which the permission of introduction is not required]. Dziennik Ustaw [Journal of Laws of the Republic of Poland]; 2012, item 1355.

15. Brylińska M, editor. Ryby słodkowodne Polski. Warszawa: Wydawnictwo Naukowe PWN; 2000.
16. Kottelat M, Freyhof J. Handbook of European freshwater fishes. Cornol: Publications Kottelat; 2007.

17. Council Directive 92/43/EEC of 21 May 1992 on the conservation of natural habitats and of wild fauna and flora. Official Journal, No. L 206, 22.7; 1992, p. 7.

18. Błachuta J. Potrzeby monitoringu ichtiofauny w świetle Dyrektywy Wodnej Unii Europejskiej. Roczniki Naukowe PZW. 2001;14(suppl.):39-45.

19. Kukuła K. Zagrożone gatunki ryb i minogów w południowo-wschodniej Polsce.. 2001;14(suppl.):235-248.

20. Przybylski M, Zięba G, Kotusz J, Terlecki J, Kukuła K. Analiza stanu zagrożenia ichtiofauny wybranych rzek Polski. Archives of Polish Fisheries. 2004;12(suppl. 2):131-142.

21. Jelonek M, Żurek R, Klich M. Ichtiofauna rzeki Wisłoka w rejonie nowo powstałego zbiornika Mokrzec (Starostwo Dębica). Supplementa ad Acta Hydrobiologica. 2002;3:69-78.

22. Jelonek M, Klich M, Żurek R. Ichtiofauna Białej Tarnowskiej. Supplementa ad Acta Hydrobiologica. 2003;6:19-28.

23. Jelonek M, Klich M, Żurek R, Ichtiofauna Dunajca od zapory zbiornika w Czchowie do ujścia do Wisły. Supplementa ad Acta Hydrobiologica. 2003;6:115-124.

24. Augustyn L, Epler P. Ichtiofauna Czarnego Dunajca. In: Augustyn L, editor. Ichtiofauna dorzecza Dunajca na początku XXI wieku. Nowy Sącz: Wydawnictwo PWSZ; 2006. p. 11-14.

25. Augustyn L, Epler P. Ichtiofauna Białego Dunajca. In: Augustyn L, editor. Ichtiofauna dorzecza Dunajca na początku XXI wieku. Nowy Sącz: Wydawnictwo PWSZ; 2006. p. 15-18.

26. Augustyn L, Epler P. Ichtiofauna dorzecza Kamienicy Nawojowskiej. In: Augustyn L, editor. Ichtiofauna dorzecza Dunajca na początku XXI wieku. Nowy Sącz: Wydawnictwo PWSZ; 2006. p. 71-76.

27. Starmach J, Jelonek M, Mazurkiewicz G, Fleituch T, Amirowicz A. Ocena aktualnego stanu ichtiofauny i możliwości produkcyjnych dorzecza Raby i jej dopływów. Roczniki Naukowe PZW. 1998;1:73-96.

28. Skóra S, Włodek JM. Ichtiofauna rzeki Soły i jej dopływów. Roczniki Naukowe PZW. 1988;1:97-121.

29. Żurek R, (editor) Dumnicka E, Jelonek M, Klich M, Kwandrans J, Wojtal A. Ichtiofauna i status ekologiczny wód Wisły, Raby, Dunajca i Wisłoki. Kraków: Institute of Nature Conservation, Polish Academy of Sciences; 2006.

30. Klich M. Wstępna charakterystyka ichtiofauny przyujściowego odcinka Sanu (od ujścia Tanwi do ujścia do Wisły) - ryby zagrożone, chronione i cenne gospodarczo. In: Ochrona środowiska, walory przyrodnicze i rozwój 
turystyki w dolinie Sanu: III Konferencja Naukowo-Techniczna "Błękitny San": materiały konferencyjne, Dubiecko, 21-22 kwietnia 2006. Dynów: Związek Gmin Turystycznych Pogórza Dynowskiego; 2006. p. 149-162.
31. Mazurkiewicz-Boroń G, Starmach J. Konsekwencje przyrodnicze przegradzania rzek. Chrońmy Przyrodę Ojczystą. 2009;65(2):83-92. 